year 1932 adds Plastoscira Egertoni, from Rostherne Mere, Cheshire, as a new species to science, while a list of a hundred new species added to the faunistic records for the two counties includes 38 Mallophaga on the birds and mammals, which Mr. H. Britten is investigating, 20 Diptera, 17 sawflies, 10 Coleoptera, 9 Hymenoptera, 3 Anoplura, and one each of Lepidoptera, Arachnida and mites. The avi-fauna records for the year include the nesting of the goldeneye and of the pochard in Cheshire for the first time, and the occurrence of a flock of knots (Calidris $c$. canutus), estimated to number 7,000 , on the Lancashire coast in July. White-fronted geese and grey lag geese are increasing in north Lancashire in winter, while tufted ducks, teal, shoveller and little owl are also reported to be increasing in parts. The main colony of Sandwich terns on Walney Island, Lancashire, was wiped out by the herring and lesser blackbacked gulls, the colony of which, established five years ago, has assumed alarming proportions. The terns from Walney went to nest at Ravenglass ternery where the Sandwich terns have increased from 12 pairs in 1930 to 70 in 1931 , and 370 in 1932. The ruff (Philomachus pugnax) is still a regular autumn migrant and records are made of the wood-sandpiper (Tringa glareola), green-sandpiper ( $T$. ochropus), greenshank ( $T$. nebularia) and grey phalarope (Phalaropus fulicarius) on passage, while large numbers of black-tailed godwits were seen in the spring on the coast. The Fauna Committee announces that it will dedicate Part 2 of its "Check List of the Fauna of Lancashire and Cheshire" to the late T. A. Coward, for many years one of the recorders of the Committee; Part 1 having been issued in 1930. Mr. A. W. Boyd is president of the Committee and H. E. Britten, Prof. S. J. Hickson and W. Mansbridge vice-presidents.

\section{National Museum of Wales}

THe annual report for 1932-33 of the National Museum of Wales shows with what fine spirit the people of Wales are supporting their progressive Museum. The opening of the exhibition galleries in the east wing threatened to be marred by the existence of a considerable debt upon the building; but a public appeal has resulted in the receipt of more than three hundred contributions, so that, as promised moneys come in, the debt will be finally extinguished. The Folk Industries Gallery in the new wing was opened to the public in July 1933. It illustrates a side of museum activity of much interest to the public. Amongst the exhibits are the plant of a woollen yarn factory, and series showing the whole range of the woollen industry in Wales, cider-making, sawing, fishing and pottery-making. An early castiron gate, an engine from Neath Abbey Iron Works and an early colliery train illustrate the transition effected by the Industrial Revolution. Special reference should be made to the reconstructions of a rural smithy and a wood-turner's shop.

\section{Cabbages and Related Crops}

THE second edition of Bulletin No. 53 of the Ministry of Agriculture ("Cabbages and Related
Green Crops"; H.M. Stationery Office, pp. 60. 1s. $3 d$. net) was issued in November 1933. It deals with the commercially useful variants of the wild Brassica oleracea, namely, cabbages and savoys, Brussels sprouts, cauliflowers, broccoli and kale. Details of cultivation in many districts are combined with extensive notes on the economic uses of various products, and numerous methods of marketing are given. Production and harvesting of seed are also discussed. The volume is designed to help the grower, and should do this effectively. A chapter on the cultivation of Brassicae as farm crops has been added to the material published in the first edition, and the whole text has been improved by the incorporation of much recent knowledge.

\section{Liverpool Observatory}

THE report of the Liverpool Observatory and Tidal Institute for 1933 records several interesting matters concerning tidal records. Experiments were made with seismographs with the view of recording the tilting of the earth due to tidal loads as well as to thermal effects. An instability in the records was traced to distortion in the structure supporting the instruments. This was overcome and satisfactory records were obtained. The work is being continued with improvements in the instruments. Another important piece of work concerns a new method of prediction of mixed diumal and semi-diurnal tides. Work was also done on the tidal bore of the Trent and on the tides of the Bay of Biscay. Tidal predictions have been worked out for various authorities.

\section{Rainfall of the World}

Most maps hitherto constructed to show the mean annual distribution of rainfall are confined to the land areas and have no indication of rainfall over the oceans. Prof. W. Meinardus has published in Petermanns Mitteilungen (1934) a new rainfall map on a scale of $1: 100,000,000$ which shows the distribution over the entire surface of the globe. On so small a scale it naturally does not differ materially so far as land areas are concerned from Supan's and other maps, although it shows effectively the low precipitation in north and south polar regions ; but over the oceans, and in particular the Indian and Pacific Oceans, there is much of interest. These details have been taken chiefly from G. Schott's oceanic maps. The map is produced in tints of two colours showing six different grades of rainfall.

\section{Study of Cosmic Rays in Armenia}

Prof. A. F. Jofre, of the Physico-Technical Institute of the U.S.S.R., is sending out a scientific expedition to Erivan to establish a laboratory for the study of the cosmic rays. It is proposed to set up the station on Mount Alagöz, in Armenia, at a height of 14,400 ft. above sea-level. The object of this station will be to investigate the distribution of the cosmic rays. The leader of the expedition is Dr. D. V. Skobeltzin. It has also been decided to set up on the shore of Lake Gokcha $(6,345 \mathrm{ft}$. above sea-level) an astrophysical observatory where a 16-in. reflector will be erected. 